\title{
ARCHIWA OTWARTE. O OBECNOŚCI ARCHIWÓW PAŃSTWOWYCH W PRZESTRZENI PUBLICZNEJ W KONTEKŚCIE ZALOŻEŃ, REALIZACJI I EFEKTÓW STRATEGII ARCHIWÓW PAŃSTWOWYCH NA LATA 2010-2020
}

\footnotetext{
Słowa kluczowe: archiwa otwarte, zasada publiczności, przestrzeń publiczna, wizerunek archiwów, działalność archiwów państwowych, udostępnianie materiałów archiwalnych, archiwa rodzinne
}

\section{Streszczenie}

Współcześnie, prowadząc politykę otwartego dostępu do zasobu, archiwa w pierwszym rzędzie zaspokajają szerokie potrzeby informacyjne jednostek i zbiorowości. Dysponując wyjątkowym potencjałem, coraz bardziej świadomie mogą kreować potrzeby społeczne, inicjować zdarzenia, oddziaływać na społeczność. Zasada publiczności archiwów staje się jedną z podstawowych zasad współczesnej archiwistyki. Jej założenia determinują działania archiwów, które coraz częściej przesuwają środek ciężkości z prac wewnętrznych na prace publiczne. Nowoczesne archiwum państwowe to przestrzeń dla spotkań i ludzi, w której archiwa są obecne w co najmniej trzech wymiarach: realnym, wirtualnym, emocjonalnym. Wymiar emocjonalny archiwów silnie oddziałuje na ich odbiór, postrzeganie, ocenę, nadaje charakter instytucji i jej wizerunek w społeczeństwie. Aby archiwa w XXI w. stawały się coraz bardziej świadomymi organizacjami, pozytywnie postrzeganymi w społeczeństwie, wymagają dobrego zarządzania, profesjonalnego podejścia i strategicznego planowania we wszystkich obszarach działalności i aktywności. Powinny świadomie dążyć do tego, aby być instytucjami pozytywnie odbieranymi w społeczeństwie, czynnie uczestniczącymi w bieżących wydarzeniach w lokalnych społecznościach, w których działają, włączającymi się aktywnie w wydarzenia organizowane przez innych, nie tylko skupiające się na własnych pomysłach. Dysponując unikatowym zasobem źródeł historycznych, połączone w sieci archiwów państwowych, powinny być atrakcyjnym partnerem dla wielu instytucji i organizacji, dla szkół, dla lokalnych władz. Budowanie pozytywnego wizerunku w społeczeństwie to realne wyzwanie, swoiste to be or not to be archiwum i skupionych w nich archiwistów. Zmiany w obszarze wizerunkowym mogą ułatwić archiwom funkcjonowanie w obliczu kolejnych wyzwań, niemniej konieczność tej zmiany archiwiści muszą najpierw zaakceptować, a sam proces zmian rozpocząć od siebie samych. 


\title{
JOANNA CHOJECKA
}

ORCID $\underline{\text { 0000-0003-3043-9500 }}$

joanna.alicja.chojecka@gmail.com

(Head Office of State Archives)

\section{OPEN ARCHIVES. ON PRESENCE OF STATE ARCHIVES IN PUBLIC SPACE IN CONTEXT OF ASSUMPTIONS, IMPLEMENTATION AND RESULTS OF STATE ARCHIVES STRATEGY 2010-2020}

Keywords: open archives, activity of state archives, access to archival materials, family archives

\begin{abstract}
Policy of open access to the fonds, conducted nowadays by the archives, first and foremost allows them to satisfy broad information needs of individuals and communities. Thanks to their unique potential, archives are increasingly able to consciously create social needs, initiate events, influence the community. The principle of public access to archives has become one of the fundamental principles of modern archivistsics. Its assumptions determine the activity of archives, which increasingly often shift the centre of balance of their work from internal work to public. A modern state archive is a space for meetings and people, in which the archives are present in at least three dimensions: real, virtual and emotional. The emotional dimension of archives has a strong impact on their perception and assessment, determines the character of the institution and its image in the society. In order to make $21^{\text {st }}$ century archives organizations that are increasingly aware, perceived positively by the society, they require good management, professional approach and strategic planning in all areas of activity. The archives should consciously aim to be perceived positively by the society, actively participate in current events in local communities, in which they operate, actively joining the events organized by others, not just focusing on their own ideas. The archives are a unique collection of historical sources, connected into a network of state archives; this should make them an attractive partner for many institutions and organizations, for schools and local authorities. Building a positive public image is a real challenge, in a manner of speaking a to be or not to be of the archives and archivists working there. A change regarding their image could make it easier for the archives to operate in face of oncoming challenges. Nonetheless, the need for such a change must be first accepted by the archivists, and they must start the process of change with themselves.
\end{abstract}


Wprawdzie idea archiwów otwartych nie pojawiła się współcześnie, jednak nie jest tendencją charakterystyczną dla ostatnich dziesięcioleci XX w. ${ }^{1}$ Stopniowe otwieranie się archiwów na potrzeby społeczne, ich wrastanie w przestrzeń publiczną jest stałym procesem, który towarzyszy archiwom państwowym niemal od pierwszego dnia ich funkcjonowania w niepodległej Polsce. Art. 11 dekretu Naczelnika Państwa z 7 lutego 1919 r. o organizacji archiwów państwowych i opiece nad archiwaliami, powołującego sieć archiwalną odrodzonego państwa, zobowiązywał archiwa do wspierania ,„...] pracy naukowej przez udostępnianie materiałów archiwalnych drogą ich publikacji oraz przez dopuszczenie do korzystania z archiwów osób prywatnych i urzędowych oraz ciał naukowych [...]"2.

W ten sposób do świadomości państwowej ówczesnych elit intelektualnych, a w szerszym rozumieniu do mentalności społecznej, została wprowadzona idea otwartości publicznej polskich archiwów państwowych. W realiach gospodarczych międzywojnia, przy ówczesnym poziomie świadomości społecznej, wiedzy i kultury dokumentacyjnej, udostępnianie archiwaliów miało ograniczony zakres, a użytkownikami były osoby uprzywilejowane ze względu na wykształcenie i pozycję społeczną. Archiwa państwowe z definicji były w służbie administracji. Ich otwarcie dla badań naukowych oznaczało wprowadzenie nowych sposobów i metod udostępniania zgromadzonych w magazynach archiwalnych zbiorów użytkownikom „obcym” - spoza archiwum. Dostęp zarezerwowano zatem dla uczonych, przy czym znanych zarządowi archiwum, mających listy polecające instytucji naukowych, a także dla urzędników państwowych i samorządowych oraz osób, które uzyskały rekomendację Wydziału Archiwów Państwowych. W praktyce, zasady dostępu do archiwów były dużo bardziej liberalne, niż wynikało to z litery prawa, ze względu na duże zainteresowanie materiałami archiwalnymi ze strony także innych badaczy, aniżeli tylko znanych archiwum i wyposażonych $\mathrm{w}$ listy uwierzytelniające. Archiwiści umożliwiali korzystanie z archiwaliów chociażby genealogom, którzy nie mieścili się w zdefiniowanej przepisami kategorii uczonych ${ }^{3}$.

Po II wojnie światowej dostęp do zasobu archiwów państwowych określały nowe akty prawne: dekret o archiwach z $1951 \mathrm{r}$. i ustawa o narodowym zasobie archiwalnym i archiwach z 1983 r., która obowiązuje do dziś, choć w wielokrotnie znowelizowanej formie. Co ciekawe, przepisy o dostępie do materiałów narodowego zasobu archiwalnego, zawarte w art. 16a ustawy, stanowiące, iż „każdemu przysługuje prawo dostępu do materiałów archiwalnych”, są bardziej

${ }^{1}$ Zasada publiczności archiwów została sformułowana w dekrecie z 25 czerwca 1794 r. w czasie rewolucji francuskiej i spowodowała otwarcie (upublicznienie) archiwów dla wszystkich obywateli.

2 Dziennik Praw Państwa Polskiego 1919, nr 14, poz. 182.

${ }^{3}$ D. Grot, Ku przeszlości otwartej. Dostępność archiwów państwowych w Polsce w latach 1918 2014, Warszawa 2015, s. 65. 
elastyczne niż tzw. ustawa re-use (ustawa z dnia 25 lutego 2016 r. o ponownym wykorzystywaniu informacji sektora publicznego $)^{4}$.

Współcześnie, prowadząc politykę otwartego dostępu do zgromadzonego zasobu, archiwa w pierwszym rzędzie zaspokajają szerokie potrzeby informacyjne jednostek i zbiorowości. Więcej, dysponując wyjątkowym potencjałem, coraz bardziej świadomie mogą kreować potrzeby społeczne, inicjować zdarzenia, oddziaływać na społeczność 5 . Zasada publiczności archiwów staje się bowiem jedną z podstawowych zasad współczesnej archiwistyki. Jej założenia determinują działania archiwów, które coraz częściej przesuwają środek ciężkości z prac wewnętrznych na prace publiczne ${ }^{6}$. Nie jest to jednak nadal trend powszechnie rozumiany i akceptowany w archiwach państwowych i przez archiwistów. Ten kierunek obecności archiwów w przestrzeni społecznej wciąż wywołuje niezrozumienie, a nawet niepokój tych archiwistów, którzy nie dostrzegają związku prac wewnętrznych archiwum $\mathrm{z}$ ich obecnością i postrzeganiem w przestrzeni publicznej. Deprecjonują oni znaczenie tych $\operatorname{prac}^{7}$ lub za najistotniejsze uważają prace wewnętrzne archiwum, a w szczególności działalność naukową ${ }^{8}$.

Współczesne archiwa mierzą się z postępem i bardzo dynamicznym rozwojem nowych technologii, a także z coraz silniej formułowanym postulatem szerokiego, powszechnego otwarcia ich zasobu. Liberalizacja dostępu do zasobu archiwalnego spowodowała, że archiwa stanęły przed nowym wyzwaniem, jakim jest komunikacja społeczna i public relations, marketing i promocja, tzn. zarządzanie wizerunkiem poprzez budowanie relacji z otoczeniem archiwów, współcześnie i w przyszłości. O tzw. miękkich kompetencjach nigdy wcześniej nie wspominano w kontekście archiwów i ich działalności lub wymagań wobec adeptów archiwistyki. Komunikacja społeczna i public relations to narzędzia, które pozwalają instytucji ugruntować się w świadomości społecznej i wypracować oczekiwane, czyli dobre, relacje $\mathrm{z}$ otoczeniem. Najważniejszym elementem w tym procesie jest nastawienie, wiara w sens działań i przekonanie o słuszności obranej drogi postępowa-

${ }^{4}$ Zob.: Ustawa z dnia 14 lipca 1983 r. o narodowym zasobie archiwalnym i archiwach (Dz.U. 1983, nr 38, poz. 173); Ustawa z dnia 25 lutego 2016 r. o ponownym wykorzystywaniu informacji sektora publicznego (Dz.U. 2016, poz. 352).

${ }^{5}$ M. Jabłońska, W poszukiwaniu złotego środka. Kilka uwag na temat wewnętrznej i publicznej pracy archiwów, [w:] Nowa archwistyka - archiwa i archiwistyka w ponowoczesnym kontekście kulturowym, Toruńskie Konfrontacje Archiwalne, t. 4, red. W. Chorążyczewski, W. Piasek, A. Rosa, Toruń 2014, s. 152.

${ }^{6}$ W. Chorążyczewski, A. Rosa, Zasada publiczności nowym paradygmatem archiwistyki?, „Archiwista Polski” 2010, 3(59), s. 23-42.

${ }^{7}$ https://www.facebook.com/archiwizjoner/, post z 4 kwietnia 2019 r. [dostęp: 06.04.2019].

${ }^{8}$ P. Gut, O miejsce archiwów państwowych $w$ badaniach nad historia regionalna, [w:] Silva rerum opera historica, diplomatica et archivistica continens, Andreae Tomczak dedicata, red. W. Chorążyczewski, M. Hlebionek, Toruń-Warszawa 2012, s. 151-160; M. Szczepaniak, G. Tyrchan, Popularyzacja i edukacja w archiwach. Gtos w sprawie hierarchii priorytetów, [w:] ibidem, s. 73. 
nia. To swoista filozofia zarządzania archiwum, która ma odmienić sposób postrzegania instytucji i stworzyć szansę na walkę ze stereotypami poprzez wzrost społecznej świadomości, edukację, rozwiniętą kulturę dokumentacyjną, a przede wszystkim rzetelną i dobrze przygotowaną informację 9 . Dystansowanie się archiwów jako sieci placówek i środowiska archiwistów od „wspólnoty interesów” nie ułatwia realizacji tych zadań. Bez wątpienia powinny być podjęte działania, zmierzające do zintegrowania środowiska, zbudowania poczucia wspólnoty interesów i identyfikacji z siecią archiwalną, rozwijania i promowania współpracy, a nie rywalizacji. Wymagać to będzie zweryfikowania sposobów myślenia, postaw i wartości, po to, żeby móc przystąpić do zmiany świadomości społecznej. Te zmiany są niezwykle istotne z punktu widzenia archiwum, jego zasobu, pracowników i otoczenia. To także kwestia dojrzałości społecznej archiwów państwowych jako organizacji i jej kadr. Stopień rozwoju tego komponentu organizacji archiwów decyduje bowiem w poważnym stopniu o ich pozycji w przestrzeni społecznej i publicznej. Dodatkową trudnością jest fakt, że efekty działań w tym zakresie będą widoczne dopiero z perspektywy długookresowej ${ }^{10}$.

W środowisku archiwów państwowych nadal powszechny jest pogląd, że praca wewnętrzna archiwów, w tym ścisłe wykonywanie zadań określonych w ustawie o narodowym zasobie archiwalnym i archiwach jest ważniejsze niż inne zadania działalności archiwalnej. Pogląd ten był ugruntowany także wśród pracowników naukowych archiwistyki. Reakcją na postulowaną od pewnego czasu w piśmiennictwie archiwistycznym, a także opisaną w Strategii archiwów państwowych na lata 2010-2020 (o czym dalej), ideę publicznej pracy archiwów, było zaostrzenie się sporu między zwolennikami archiwów elitarnych i otwartych. Postawa tych pierwszych wynika być może z poczucia zagrożenia i obawy, że pod naporem archiwalnych edukatorów, popularyzatorów, nierzadko sympatyzujących $\mathrm{z}$ nieprofesjonalnymi historykami (niesłusznie nazywanych pseudonaukowcami), $\mathrm{z}$ archiwów znikną etatowi badacze ${ }^{11}$. Nic bardziej mylnego. Działania popularyzatorskie, takie jak scenariusze wystaw, koncepcje konferencji naukowych, wydawnictw, działań edukacyjnych, założenia projektów badawczych itp., opierają się właśnie na pracy wewnętrznej archiwów i dorobku archiwistów z naukowym powołaniem, będących nierzadko wysoko cenionymi autorytetami. Parafrazując słowa poety, dla każdego starczy nieba pod wielkim dachem archiwów. Istotne jest zrozumienie zmieniających się funkcji archiwów i zaakceptowanie nieuchronnych zmian warunków, w jakich one działają. Istotna

${ }^{9}$ M. Jabłońska, Nowe wyzwania archiwów. Komunikacja społeczna i public relations, Toruń 2016, s. 8.

${ }_{10}$ Ibidem, s. 9.

11 W. Chorążyczewski, Polska myśl archiwalna okresu międzywojennego w powszechnym dyskursie archiwistycznym, [w:] Archiwa w Niepodległej. Stulecie archiwów państwowych 1919-2019, Warszawa 2019, s. 39. 
jest także solidarna współpraca archiwistów na rzecz instytucji i realizacji jej misji.

Naczelny dyrektor archiwów państwowych oraz niektóre archiwa państwowe, mimo oporów środowiskowych, intuicyjnie coraz silniej skłaniały się ku pracy publicznej. Przełomem było sformułowanie koncepcji i celów działalności archiwów państwowych z perspektywy potrzeb szeroko rozumianego społeczeństwa, przede wszystkim prawa do informacji. W prekursorskim dla wspólnej koncepcji działania archiwów państwowych dokumencie, jakim była Strategia archiwów państwowych na lata 2010-2020 $0^{12}$, jasno i wyraziście został sformułowany cel i istota działalności archiwów państwowych we współczesnym społeczeństwie. Strategia stała się punktem wyjścia do kreowania odpowiedzialnego wizerunku instytucji, rozumianego jako całokształt wyobrażeń, odczuć i oczekiwań społecznych, dotyczących archiwów, a zatem także wyobrażeń i odczuć dotyczących efektów prac wewnętrznych i publicznej aktywności archiwów.

Nieprzypadkowo dwa z czterech celów operacyjnych wspomnianej Strategii zorientowano na obecność archiwów państwowych w społeczeństwie i budowanie z nim relacji. Te cele, to zaspokajanie informacyjnych potrzeb społeczeństwa oraz budowanie wizerunku archiwów państwowych jako nowoczesnych i przyjaznych instytucji, aktywnie uczestniczących w procesie edukacji społeczeństwa otwartego. Przyjęto, iż ich realizacja powinna odbywać się poprzez różne działania w sferze szeroko rozumianej kultury i przestrzeni społecznej. Odwołano się więc bezpośrednio do obecności archiwów państwowych w społeczeństwie, zakładając, że racją tej obecności jest inspirowanie społeczeństwa do budowania więzi, przepływ informacji i wyzwalanie inicjatywy. W dokumencie sformułowano także misję archiwów jako „[...] trwałe zachowanie świadectw przeszłości i zapewnienie do nich powszechnego dostępu w celu wspierania rozwoju państwa i społeczeństwa obywatelskiego".

Archiwa państwowe, jako instytucje powołane do zabezpieczenia pamięci zbiorowej państwa i narodu, utrwalonej w dokumentalnych świadectwach ich działalności, biorą na siebie odpowiedzialność za tę pamięć, za pamięć jednostek i zbiorowości, za skarbnicę źródeł, które pamięć tę budują i utrwalą. Dostarczają bowiem źródeł do badań naukowych i odtwarzania wydarzeń z przeszłości, dając podstawę do ich analizy i interpretacji, nadawania znaczenia faktom historycznym i konstruowania narracji historycznej. Zadaniem archiwów jest zatem zabezpieczenie i sprawne udostępnienie zgromadzonych źródeł historycznych; to ich najważniejszy wkład w rozwój badań naukowych i poznawanie przeszłości. Nie mniej ważne jest kształtowanie zasobu archiwalnego i polityka jego gromadzenia. To co dziś znajduje się w magazynach archiwalnych jest konsekwencją

12 „Misją [archiwów] jest trwałe zachowanie świadectw przeszłości i zapewnienie do nich powszechnego dostępu w celu wspierania rozwoju państwa i społeczeństwa obywatelskiego", Strategia archiwów państwowych na lata 2010-2020, Warszawa 2011, https://www.archiwa.gov.pl/images/ docs/Strategia archiww pastwowych na lata 2010 2020.pdf [dostęp: 20.04.2019]. 
podejmowanych w przeszłości działań na rzecz zabezpieczenia najcenniejszych materiałów i tego, co udało się uchronić przed destrukcyjnym działaniem czasu i ludzi.

Współcześnie archiwa mają realny wpływ na konstrukcję zasobu archiwalnego i na to, co trafia do ich magazynów. Poza działalnością instytucjonalną, obejmującą nadzór nad podległymi podmiotami, duże znaczenie mają także działania, które wpływają na sposób myślenia społeczeństwa o przeszłości. Działania, które mają pokazywać, że to, co pozostanie po nas, w dużej mierze zależy od nas samych, od tego, jak dokumentujemy, i od tego, jak zabezpieczymy wytworzone i zgromadzone materiały. Temu służą działania edukacyjne, w tym lekcje archiwalne adresowane do dzieci i młodzieży, współpraca z nauczycielami, opracowywanie scenariuszy lekcji i warsztatów, zapraszanie do archiwum i wizyty w szkołach ${ }^{13}$. W ten sposób archiwa biorą aktywny udział w edukacji historycznej młodych ludzi, pokazują im przeszłość zapisaną w zgromadzonych źródłach, ale i odkrywają same archiwa, wskazując na charakter i znaczenie ich pracy. Lekcje archiwalne mają za cel popularyzację wiedzy o archiwach i materiałach archiwalnych, promocję i budowanie ich pozytywnego wizerunku jako instytucji nowoczesnych i aktywnych w procesie edukacji społeczeństwa. To także propagowanie wiedzy historycznej, zwłaszcza w jej regionalnym wymiarze, rozbudzenie zainteresowania genealogią i dziejami własnej rodziny, zapoznanie uczniów z oryginalnymi dokumentami i warsztatem pracy historyka i archiwisty, wspieranie szkolnej edukacji historycznej, kształtowanie kultury źródłoznawczej oraz kultury i świadomości historycznej ${ }^{14}$. Adresatem tej aktywności są przede wszystkim placówki oświatowe. Działalność na tym polu ma zorganizowaną formę, określonych odbiorców, cele, metody i środki. Udział $\mathrm{w}$ niej biorą uczniowie i nauczyciele, nie w czasie wolnym, ale w ramach swoich obowiązków.

Archiwa państwowe podejmują wiele inicjatyw skierowanych do innych, niż wspomniane grup odbiorców, do osób, które nie stykają się na co dzień z historią. Starają się uaktywniać społeczności niezależnie od profilu zawodowego bądź wykształcenia. Zapraszają do uczestnictwa $\mathrm{w}$ wydarzeniach popularno-naukowych w czasie wolnym, zachęcając do rozwijania własnych pasji i zainteresowań, rozbudzając chęć poznania przeszłości. Przykładem dobrych praktyk jest projekt „Archiwa rodzinne” przygotowany pod hasłem „Zostań rodzinnym

${ }^{13}$ Zob. m.in.: Archiwum jako warsztat pracy nauczyciela historii. Scenariusze lekcji dla nauczycieli szkoly podstawowej, gimnazjum i szkoty ponadgimnazjalnej, pod red. T. Stachurskiej-Maj i V. Urbaniak, Warszawa 2010; A. Rosa, Funkcja edukacyjna archiwów, Warszawa 2012; H. Mazur, Lekcje archiwalne - próba definicji, cele, typologia, budowa, „Archiwista Polski” 2013, nr 1(69), s. 7-23; idem, A. Rosa, Lekcje archiwalne. Skrypt przygotowany na potrzeby spotkania Forum Edukatorów Archiwalnych, Kielce-Torun 2015; Educare necesse est - ale jak i dlaczego? Przyktady dobrych praktyk edukacyjnych, red. nauk. V. Urbaniak, Warszawa 2017.

${ }^{14}$ H. Mazur, op.cit., s. 20. 
archiwistą". Projekt adresowany był do osób, dla których historia własnej rodziny jest ważna, miał oddziaływać na społeczną wyobraźnię, zachęcić do współpracy, zaktywizować społeczność wokół idei archiwów prywatnych ${ }^{15}$. Współpraca z Polskim Radiem zapewniła rozgłos, forma konkursu wywołała emocje, a punkty konsultacyjne skróciły dystans pomiędzy archiwami państwowymi a twórcami archiwów rodzinnych ${ }^{16}$. Kontynuacją jest nowy projekt „Archiwa Rodzinne Niepodległej" $\mathrm{z}$ roku 2019, realizujący podobne cele ${ }^{17}$ : przybliżenie archiwów i ich działalności lokalnej społeczności i obywatelom. Znaczenie ma wybór optymalnego terminu, wpisanie się w lokalne wydarzenia i obchody rocznicowe, dobór partnerów, a także tematyka, która powinna być ważna dla adresatów imprezy. Bez wątpienia tego typu projekty, uwrażliwiając na przeszłość, zmuszają do refleksji nad tym, co było i nad tym, co po nas pozostaje. Oddziałują bezpośrednio na postawę ludzi, ich kulturę dokumentacyjną ${ }^{18}$, wrażliwość historyczną i świadomość archiwalną.

Ustanowienie przez naczelnego dyrektora archiwów państwowych od $2019 \mathrm{r}$. dzień 30 września Dniem Archiwisty, sprzyjać ma budowaniu relacji z otoczeniem archiwów i stwarza okazję do rozmowy zarówno o zawodzie, jak i pasji, zadaniach archiwów, archiwaliach i historii ${ }^{19}$. Dzień 30 września wybrano z dwóch powodów. Po pierwsze, to dzień św. Hieronima ze Strydonu, patrona archiwistów, bibliotekarzy, biblistów i tłumaczy. Po drugie, wrzesień jest miesiącem obchodów Europejskich Dni Dziedzictwa, w które archiwa, ze zgromadzonym dziedzictwem dokumentacyjnym, wpisują się jako instytucje pamięci i dziedzictwa narodowego. W 2019 r. odbyły się z tej okazji warsztaty archiwalne i liczne przedsięwzięcia poświęcone tematyce archiwów rodzinnych, z udziałem rodzinnych archiwistów.

Efekty aktywnego wychodzenia instytucji archiwalnych do społeczeństwa, przy jednoczesnym zabezpieczeniu pracy bieżącej, są dostrzegalne i nierzadko wysoko oceniane i doceniane zarówno w skali całej sieci archiwów państwowych, jak i w skali regionalnej. Właśnie na lokalnym poziomie archiwa państwowe coraz dynamiczniej wpisują się w krajobraz instytucji, nierzadko wiodą-

${ }^{15}$ Archiwa rodzinne, https://www.archiwa.gov.pl/pl/809-archiwa_rodzinne [dostęp: 20.08.2019].

${ }_{16}$ B. Karwalska, Archiwa rodzinne w archiwach państwowych $i$ konkurs dla archiwistów rodzinnych w Archiwum Państwowym w Poznaniu, „Przegląd Archiwalno-Historyczny” 2016, t. 3, s. 243.

${ }^{17}$ Archiwa Rodzinne Niepodległej, https://www.nac.gov.pl/wiedza-i-edukacja/archiwa-rodzinne-niepodleglej/ [dostęp: 21.08.2019].

${ }^{18}$ Mówiąc o kulturze dokumentacyjnej, nie należy jej analizować wyłącznie w kategoriach instytucjonalnych. Stanowi ona bowiem ślad ludzkiej działalności i obejmuje nie tylko przedmioty, które stanowią dokumenty i dokumentacja, ale również wzorce i wartości, zachowania i czynności. Wśród jej wskaźników odnaleźć można wiedzę na temat dokumentów i dokumentacji oraz świadomość ich funkcji społecznej i kulturalnej, a także poszanowanie dokumentacji jako wspólnego dziedzictwa narodowego. Zob.: W.K. Roman, Współczesna kultura dokumentacyjna, Torun 2013, s. 48.

19 Pismo Naczelnego Dyrektora Archiwów Państwowych do Archiwów Państwowych z dnia 28 sierpnia 2019 r., znak DOU.0661.3.2019. 
cych, proponujących ciekawą ofertę kulturalną, edukacyjną i naukową, a praca publiczna archiwów nabiera szczególnego znaczenia, gdy realizowane są we współpracy z różnorodnymi partnerami krajowymi i zagranicznymi. To nie tylko samorządy, instytucje kultury, ośrodki naukowe, placówki oświatowe, ale też podmioty rynkowe, chociażby z obszaru turystyki, a także prężnie rozwijające się organizacje pozarządowe. Pierwsze próby na tym polu pokazały, że archiwiści poprzez promowanie i edukowanie docierają do tej części społeczeństwa (potencjalnych klientów), która nie zna archiwów, ich misji i zasobu.

Działalność publiczna archiwów państwowych to całe spektrum możliwości oddziaływania w regionie, kraju i za granicą i to zarówno w wymiarze całej sieci archiwalnej, jak i w wymiarze pojedynczej instytucji. Według sprawozdania z działalności archiwów państwowych w 2018 r., w archiwach zorganizowano ogółem 419 wystaw tradycyjnych (w tym 180 własnych) oraz 597 wirtualnych (w tym 590 własnych), przyjęto 542 wycieczki, w których wzięło udział 15854 uczestników. Archiwiści przygotowali 415 publikacji, zrealizowali 995 projektów edukacyjnych i przeprowadzili 847 lekcji archiwalnych, odnotowano blisko 865 tys. odwiedzin stron internetowych archiwów państwowych. Archiwa organizowały bądź współorganizowały wiele konferencji, archiwiści uczestniczyli w 304 krajowych i międzynarodowych konferencjach, seminariach i sesjach, podczas których wygłosili 329 referatów. Naczelny dyrektor archiwów państwowych przyznał dofinansowanie 13 projektom popularyzującym wiedzę o materiałach archiwalnych i archiwach oraz 14 projektom wydawniczym i 17 czasopismom naukowych wydawanym przez archiwa państwowe. Nakładem Naczelnej Dyrekcji Archiwów Państwowych ukazało się drukiem dziewięć publikacji z dziedziny szeroko rozumianej archiwistyki. To tylko część efektów działalności archiwów państwowych w 2018 r. W latach 2014-2018 zorganizowano 2084 wystawy tradycyjne, w tym 733 własne, przyjęto 2969 wycieczek z 91061 uczestnikami, nakładem archiwów ukazało się 2135 publikacji, zrealizowano 5100 projektów edukacyjnych, w tym 3491 lekcji archiwalnych, przygotowano 14240 materiałów i informacji medialnych o archiwach $^{20}$. Liczby te pokazują, jak bardzo aktywne są archiwa w przestrzeni publicznej i jak silnie starają się zaznaczyć swoją obecność.

Nową formą aktywności są akcje społeczne i wydarzenia plenerowe, przyciągające do archiwów państwowych tysiące uczestników, organizowane najczęściej w ramach cyklicznych wydarzeń kulturalnych, takich jak Noc Muzeów, Noc Kultury, Europejskie Dni Dziedzictwa, a także Międzynarodowy Dzień Archiwów. Noc Muzeów zorganizowana w 2015 r. przez Archiwum Państwowe w Koszalinie pn. „Plon, niesiemy plon, czyli dożynkowych wspomnień czar...”

${ }^{20}$ Sprawozdania Naczelnego Dyrektora Archiwów Państwowych KN-1 działalność archiwalna według stanu na dzień 31 grudnia 2018 r., 31 grudnia 2017 r., 31 grudnia 2016 r., 31 grudnia 2015 r. i 31 grudnia 2014 r., https://www.archiwa.gov.pl/files/.pdf [dostęp: 20.08.2019]. 
(wzięło w niej udział ok. 5 tys. uczestników) została uznana za wydarzenie kulturalne roku podczas VIII Koszalińskiej Gali Kultury ${ }^{21}$. W kolejnych latach koszalińskie archiwum zorganizowało dwie edycje Nocy Archiwów, które spotkały się z równie dużym zainteresowaniem i liczną frekwencją. Rozpoznawalność i marka, jaką to archiwum wypracowało sobie w regionie, gwarantowało uczestnikom atrakcyjne, ciekawe wydarzenie i interesująco spędzony czas. Duże zainteresowanie ogólnopolskim przedsięwzięciem „Archiwa rodzinne”, zainaugurowanym w 2014 r., i jego kontynuacją w formie kolejnych projektów, takich jak wspomniane już „Archiwa Rodzinne Niepodległej” w 2019 r., są potwierdzeniem, że archiwa państwowe w przestrzeni społecznej pełnią rolę ważnych, instytucjonalnych partnerów indywidualnych spotkań z historią.

Całkiem odmienny charakter mają działania, które można określić jako „cyfrowe uwalnianie archiwów". To proces digitalizacji materiałów archiwalnych, realizowany w archiwach państwowych w bardzo szerokim zakresie. Działanie to wychodzi naprzeciw trendom i oczekiwaniom społecznym, a tym samym zaspokaja potrzeby informacyjne obywateli, także tych, którzy nie zawsze potrafią samodzielnie wyszukać interesujące ich materiały. Digitalizacja i publikowanie online cyfrowych kopii (skanów) archiwaliów stanowią dla archiwów wyśmienite narzędzie do kreowania wizerunku instytucji nowoczesnych i otwartych na oczekiwania współczesnego użytkownika. Jednocześnie, dzięki dobrej komunikacji, zdobywaniu rozgłosu i płynnemu przepływowi informacji archiwa mają szansę dotrzeć do realnych i potencjalnych użytkowników zasobu archiwalnego. Skany dokumentów archiwalnych udostępnianie są zarówno w pracowniach naukowych archiwów, jak i na ich stronach internetowych, a przede wszystkim na portalu szukajwarchiwach.gov.pl, koordynowanym przez Narodowe Archiwum Cyfrowe. Portal udostępnia ponad 37 mln skanów ${ }^{22}$ źródeł historycznych z zasobu państwowych, w tym m.in. ksiąg metrykalnych, akt urzędów stanu cywilnego i wielu innych. To prawdziwy raj dla genealogów, miłośników historii, ale też dla zawodowych historyków, dla których stał się ważnym narzędziem badań źródłowych. W ostatnim czasie dostrzec można nowe zjawisko, że bywanie chociażby wirtualne - w archiwach, stało się coraz bardziej modne, w ślad za rosnącym zainteresowaniem genealogią i regionalistyką. „Czytanie” zdigitalizowanych źródeł, dzielenie się odkryciami, wiedzą, umiejętnościami, a także dyskusje i wymiana doświadczeń w mediach społecznościowych, stają się nowym trendem również $\mathrm{w}$ tej tematyce.

Niezwykle istotnym partnerem obecności archiwów państwowych w przestrzeni publicznej są media. Archiwa niejednokrotnie przekonywały się (i nadal przekonują), jak dotkliwy jest brak informacji o organizowanych przez nich

${ }^{21}$ https://gk24.pl/prezydent-koszalina-wreczyl-nagrody-ludziom-kultury-zdjecia/ar/9813394; http://koszalin.ap.gov.pl/stara/index.php/pl/component/content/article/35-aktualnoci/874-gala-kultury-31032016-r.html [dostęp: 30.08.2019].

${ }^{22}$ Stan na wrzesien $2019 \mathrm{r}$. 
przedsięwzięciach i działaniach. Nadal brakuje w archiwach wiedzy o organizowaniu kampanii medialnych na temat działalności i wydarzeń, brakuje także umiejętności budowania i utrzymywania relacji z mediami. W sukurs archiwom, nadal niedostatecznie obecnym i rozpoznawalnym w przestrzeni medialnej, przyszły media społecznościowe. To silny środek masowej informacji, także wizerunkowy, ciągle jeszcze niedostatecznie wykorzystywany w promocji działań archiwów państwowych. Powodów jest kilka. Najważniejszy to nadal zbyt niska akceptacja tego mass medium i wynikająca $\mathrm{z}$ tego niewielka obecność w strukturze zatrudnienia archiwów państwowych osób odpowiednio przygotowanych, z kwalifikacjami odpowiednimi do nowych warunków działalności i wymagań współczesności. Gdzie tkwi zatem problem? Za kształtowanie kadr i kierunek rozwoju instytucji odpowiada dyrektor oraz kadra kierownicza. Są oczywiście w sieci archiwów państwowych pozytywne przykłady, gdzie zarówno współpraca z mediami tradycyjnymi, jak i umiejętności korzystania z mediów społecznościowych są naprawdę dobre, w zależności do tego, jakie kryterium przyjmiemy. Najprostszym jest oczywiście liczba polubień, czy obserwujących profil archiwum w mediach społecznościowych, reakcje na posty, liczba udostępnień i komentarzy. Liderem jest Narodowe Archiwum Cyfrowe, które bardzo wcześnie postawiło na silną kampanię wizerunkową w mediach, stawiając na atut, jakim jest wyjątkowy fotograficzny i audiowizualny zasób.

Istotnym działaniem naczelnego dyrektora archiwów państwowych w przestrzeni publicznej, oddziaływującej bezpośrednio na zachowanie uniktowych źródeł historycznych spoza zasobu archiwów państwowych, jest realizacja zadania publicznego, polegającego na wspieraniu działań archiwalnych twórców państwowego i niepaństwowego zasobu archiwalnego ${ }^{23}$. W konkursach zrealizowanych w latach 2016-2019 na kwotę blisko 3 mln złotych dofinansowano 87 beneficjentów i 92 projekty złożone przez kościoły i związki wyznaniowe, fundacje, stowarzyszenia i inne organizacje społeczne.

Nie można zapomnieć o obecności archiwów państwowych w działaniach międzynarodowych, koordynowanych przez naczelnego dyrektora archiwów państwowych. To udział $\mathrm{w}$ dużych, prestiżowych przedsięwzięciach, jak np. Program UNESCO Pamięć Świata, Program Reconstitution of the Memory of Poland, projekt Europejskiego Portalu Archiwalnego APEX, program pomocy archiwalnej dla instytucji polonijnych w ramach programu operacyjnego Dziedzictwo Kulturowe - Ochrona dziedzictwa narodowego poza granicami kraju,

${ }^{23}$ Konkursy „Wspieranie działań archiwalnych” organizowane są przez naczelnego dyrektora archiwów państwowych, na podstawie ustawy z dnia 14 lipca 1983 r. o narodowym zasobie archiwalnym i archiwach (Dz.U. 2018, poz. 217, z późn. zm.), ustawy z dnia 24 kwietnia 2003 r. o działalności pożytku publicznego i o wolontariacie (Dz.U. 2018, poz. 450, z późn. zm.), ustawy z dnia 27 sierpnia 2009 r. o finansach publicznych (Dz.U. 2017, poz. 2077, z późn. zm.), https://www.archiwa. gov.pl/pl/dla-uzytkownikow/wsp $\% \mathrm{C} 3 \% \mathrm{~B} 3 \% \mathrm{C} 5 \% 82$ praca,-projekty,-dotacje/dotacje-ndap [dostęp: 30.08.2019]. 
a także współpraca transgraniczna i międzynarodowa wymiana archiwalna, realizowana przez poszczególne archiwa.

Konkludując, można stwierdzić, że niezmiennie i bezspornie celem nadrzędnym archiwów państwowych jest trwałe zachowanie świadectwa przeszłości oraz zapewnienie do niego dostępu w celu wspierania rozwoju państwa i społeczeństwa obywatelskiego. Z kolei wobec faktu, że archiwa państwowe przestały być azylem zarezerwowanym dla wąskiej elity badaczy i każdy może korzystać na równych zasadach $\mathrm{z}$ archiwum $\mathrm{z}$ jakiegokolwiek powodu, powinnością archiwum stał się obowiązek (misja) uświadamiania tego przywileju korzystania z dóbr kultury szerokiemu odbiorcy i zachęcać go do tego w różnych formach i różnymi kanałami komunikacyjnymi. To z kolei jest możliwe dzięki mocnym i trwałym podwalinom pod działalność publiczną, jakie powstają w wyniku prac wewnętrznych archiwum. Ich poziom i jakość silnie oddziałuje na sposób postrzegania instytucji w jej otoczeniu, pozyskiwaniu uznania i życzliwości publicznej. Warto przy tym podkreślić, że beneficjentami obecności archiwów w przestrzeni publicznej, bez wątpienia, są one same, ich pracownicy i zasób ale także społeczeństwo, które dzięki podejmowanym działaniom zdobywa wiedzę, umiejętności, zmienia swoje przyzwyczajenia czy też swój sposób postrzegania teraźniejszości i przeszłości. Współczesne archiwum państwowe to swoiste uniwersum - przestrzeń dla spotkań i ludzi; przestrzeń, w której archiwa są obecne w co najmniej trzech wymiarach: realnym, wirtualnym, emocjonalnym. Archiwa w wymiarze emocjonalnym, który silnie oddziałuje na ich odbiór, postrzeganie, ocenę, tworzą ludzie - to od nich, ich postaw, stosunku do samych siebie i innych oraz jakości pracy, zależy charakter instytucji i jej wizerunek w społeczeństwie.

Aby archiwa stawały się coraz bardziej świadomymi organizacjami, pozytywnie postrzeganymi w społeczeństwie, wymagają dobrego zarządzania, profesjonalnego podejścia i strategicznego planowania we wszystkich obszarach działalności i aktywności. Powinny świadomie dążyć do tego, aby być korzystnie „widzialnymi” instytucjami, czynnie uczestniczącymi także w bieżących wydarzeniach, włączającymi się aktywnie w wydarzenia organizowane przez innych, nie tylko skupiające się na własnych pomysłach. Dysponując tak unikatowym zasobem źródeł historycznych, połączone w sieci archiwów państwowych, powinny być atrakcyjnym partnerem dla wielu instytucji i organizacji, dla szkół, dla lokalnych władz. Budowanie pozytywnego wizerunku w społeczeństwie to realne wyzwanie, swoiste to be or not to be archiwum i skupionych w nich archiwistów. Z całą pewnością zmiany, także w obszarze wizerunkowym, mogą ułatwić archiwom funkcjonowanie w obliczu kolejnych wyzwań. Niemniej konieczność zmian archiwiści muszą najpierw zaakceptować, a proces ewolucji rozpocząć od siebie samych i swoich postaw. 


\section{Źródla}

Ustawa z dnia 14 lipca 1983 r. o narodowym zasobie archiwalnym i archiwach (Dz.U. 1983, nr 38, poz. 173).

Ustawa z dnia 25 lutego 2016 r. o ponownym wykorzystywaniu informacji sektora publicznego (Dz.U. 2016, poz. 352).

Ustawa z dnia 24 kwietnia 2003 r. o działalności pożytku publicznego i o wolontariacie (Dz.U. 2018, poz. 450, z późn. zm.).

Ustawa z dnia 27 sierpnia 2009 r. o finansach publicznych (Dz.U. 2017, poz. 2077, z późn. zm.).

Dziennik Praw Państwa Polskiego 1919, nr 14, poz. 182.

Sprawozdania Naczelnego Dyrektora Archiwów Państwowych KN-1 działalność archiwalna według stanu na dzień 31 grudnia 2018 r., 31 grudnia 2017 r, 31 grudnia 2016 r., 31 grudnia 2015 r. i 31 grudnia 2014 r., https://www.archiwa.gov.pl/pl/files/.pdf [dostęp: 20.08.2019].

Strategia archiwów państwowych na lata 2010-2020, Warszawa 2011, https://www.archiwa.gov.pl/ images/docs/Strategia_archiww_pastwowych_na lata_2010_2020.pdf [dostęp: 20.04.2019].

\section{Bibliografia}

Archiwa polskie wczoraj i dziś, Warszawa 2012.

Archiwa Rodzinne Niepodległej, https://www.nac.gov.pl/wiedza-i-edukacja/archiwa-rodzinne-niepodleglej/ [dostęp: 21.08.2019].

Archiwa rodzinne, https://www.archiwa.gov.pl/pl/809-archiwa_rodzinne [dostęp: 20.08.2019].

Archiwum jako warsztat pracy nauczyciela historii. Scenariusze lekcji dla nauczycieli szkoły podstawowej, gimnazjum i szkoły ponadgimnazjalnej, pod red. T. Stachurskiej-Maj i V. Urbaniak, Warszawa 2010.

Chorążyczewski W., Polska myśl archiwalna okresu międzywojennego w powszechnym dyskursie archiwistycznym [w:] Archiwa w Niepodległej. Stulecie archiwów państwowych 1919-2019, Warszawa 2019, s. 37-58.

Chorążyczewski W., Rosa A., Zasada publiczności nowym paradygmatem archiwistyki?, „Archiwista Polski” 2010, nr 3(59), s. 23-42.

Educare necesse est - ale jak i dlaczego? Przyktady dobrych praktyk edukacyjnych, red. nauk. V. Urbaniak, Warszawa 2017.

Grot D., Ku przeszłości otwartej. Dostepność archiwów państwowych w Polsce w latach 19182014, Warszawa 2015.

Gut P., O miejsce archiwów państwowych $w$ badaniach nad historia regionalna, [w:] Silva rerum opera historica, diplomatica et archivistica continens, Andreae Tomczak dedicata, red. W. Chorążyczewski, M. Hlebionek, Toruń-Warszawa 2012, s. 151-160.

Jabłońska M., Edukacyjny i promocyjny wymiar public relations $w$ archiwach, [w:] Educare necesse est-ale jak i dlaczego? Przyktady dobrych praktyk, red. nauk. V. Urbaniak, Warszawa 2017, s. 261-269.

Jabłońska M., Nowe wyzwania archiwów. Komunikacja społeczna i public relations, Toruń 2016. 
Jabłońska M., W poszukiwaniu złotego środka. Kilka uwag na temat wewnętrznej i publicznej pracy archiwów, [w:] Nowa archiwistyka - archiwa i archiwistyka w ponowoczesnym kontekście kulturowym, Toruńskie Konfrontacje Archiwalne, t. 4, red. W. Chorążyczewski, W. Piasek, A. Rosa, Torun 2014, s. 149-161.

Karwalska B., Archiwa rodzinne $w$ archiwach państwowych $i$ konkurs dla archiwistów rodzinnych w Archiwum Państwowym w Poznaniu, „Przegląd Archiwalno-Historyczny” 2016, t. 3 , s. $243-250$.

Mazur H., Lekcje archiwalne - próba definicji, cele, typologia, budowa, „Archiwista Polski” 2013, nr 1(69), s. 7-23.

Mazur H., Rosa A., Lekcje archiwalne. Skrypt przygotowany na potrzeby spotkania Forum Edukatorów Archiwalnych, Kielce-Torun 2015.

Mazur H., Rosa A., Przegląd edukacyjnych inicjatyw filmowych w polskich archiwach, [w:] Educare necesse est - ale jak i dlaczego? Przykłady dobrych praktyk edukacyjnych, red. nauk. V. Urbaniak, Warszawa 2017, s. 238.

Raport Naczelnego Dyrektora 2013, Warszawa 2014.

Raport Naczelnego Dyrektora 2014, Warszawa 2015.

Raport z działalności Naczelnej Dyrekcji Archiwów Państwowych i Archiwów Państwowych za lata 2008-2009, Warszawa 2010.

Roman W.K., Wspótczesna kultura dokumentacyjna, Torun 2013.

Rosa A., Funkcja edukacyjna archiwów, Warszawa 2012.

Szczepaniak M., Tyrchan G., Popularyzacja i edukacja w archiwach. Głos w sprawie hierarchii priorytetów, [w:] Silva rerum opera historica, diplomatica et archivistica continens, Andreae Tomczak dedicata, red. W. Chorążyczewski, M. Hlebionek, Toruń-Warszawa 2012, s. 67-73. 